\title{
Rangeland Seeder Development Using Semicircular Seed- box and Auger Agitator Seed Metering Concept
}

\section{H.T. WIEDEMANN AND B.T. CROSS}

\section{Abstract}

A rangeland seeder featuring a semicircular seedbox and auger agitator mounted to heavy-duty frame has proven reliable and durable under rough rangeland conditions. The experimental seeder reduces the variability in metering fluffy seed due to the improvement in design. Satisfactory metering of slick seed was accomplished with a commer cial, cup-feed mechanism. Flexing, runner openers prepared and placed seed in a furrow without undue mechanical breakage while traversing logs, stumps and other debris left after rootplowing. The features of the experimental seeder increase the potential for seeding brush-infested rangeland because of improved reliability and less need for costly clean-up of brush debris.

Authors are associate professor and research assistant, Texas Agricultural Experiment Station, P.O. Box 1658, Vernon, Texas 76384.

This article is approved as Technical TA-15572 from the Texas Agricultural Experiment Station.

Mention of trade name is for identification only and does not imply an endorsement or preference over other products not mentioned.

The authors are appreciative for the excellent cooperation and financial support provided in part by the Brush Control and Range Improvement Association, Abilene; Pitchfork Land and Cattle Co.. Guthrie: Gene Whitehead Ranch, Menard; Lorin McDowell Ranch, Big Spring; W.T. Waggoner Estate, Vernon; Clayton Williams Ranch, Alpine; George Warner Seed Co., Hereford; Post Contractors, Post: Malcom Otto, Conservation Contractor, Llano; Montey Munsell, Conservation Contractor Mason; Guy Goen, Conservation Contractor, Spur; Clay Caldwell, E.L. Caldwell and Sons, Inc., Corpus Christi; Soil Conservation Service; Texas Agricultural Extension Service; and Darwin Paden, V.E. Jones and G.G. Schulz, Texas Agricultural Experiment Station, who assisted in the research.

Manuscript received November 19, 1979.
There is a current world-wide awareness of the need to maximize production from all usable land sources. Rootplowing and reseeding of brush infested rangeland to productive grasses and forage plants offer excellent potential for increasing productivity of the range resource. Much of the seeding equipment for rangeland has been adapted from cropland farming equipment and requires extensive, costly, land clearing preparation for proper operation of equipment.

In 1969, The Texas Agricultural Experiment Station at Lubbock initiated a rangeland reseeding study utilizing a standard Nesbit grass drill; rangeland drill developed by Agricultural Research Service, USDA in New Mexico; cultipacker drill with Nesbit seedbox; and exhaust-blower broadcast seeder. Many inadequacies of design, seed metering, and seed placement were experienced in these trials (Brock et al. 1970). Research was then undertaken to develop a new concept for a rangeland seeder suitable for seeding rough, log-littered rangeland.

\section{Seed Metering Devices}

In a laboratory investigation, the fluffy seed metering mechanism from a Nesbit drill experienced a 99\% reduction in the seeding rate before $75 \%$ of the seed were metered from the seedbox under static conditions using sideoats gramma (Bouteloua curtipendula 
(Michx.) Torr.) grass seed and pickerwheel speed of $30 \mathrm{rpm}$. Bridging of the seed near the pickerwheel appeared to be the main problem.

A semicircular seedbox was constructed to allow seed in the seedbox to be rotated and prevent seed bridging. Pickerwheel widths of $6.4,12.7,25.4,50.8$, and $101.6 \mathrm{~mm}(1 / 4,1 / 2,1,2$, and $4 \mathrm{in})$, and agitator styles of fingers, paddles, and augers were evaluated as outlined by Wiedemann et al. (1976). A combination of the semicircular seedbox, auger agitator, and $12.7-\mathrm{mm}(1 / 2$-in) wide pickerwheel with eight teeth gave the best results. This experimental metering device produced a seeding rate decrease of only $15 \%$ while metering $75 \%$ of the seed from the seedbox at a pickerwheel speed of $10 \mathrm{rpm}$ (Fig. 1). The $10 \mathrm{rpm}$ seeding rate was comparable to 30 rpm rate of the standard Nesbit drill. The experimental unit easily

\section{SEEDER COMPARISON}

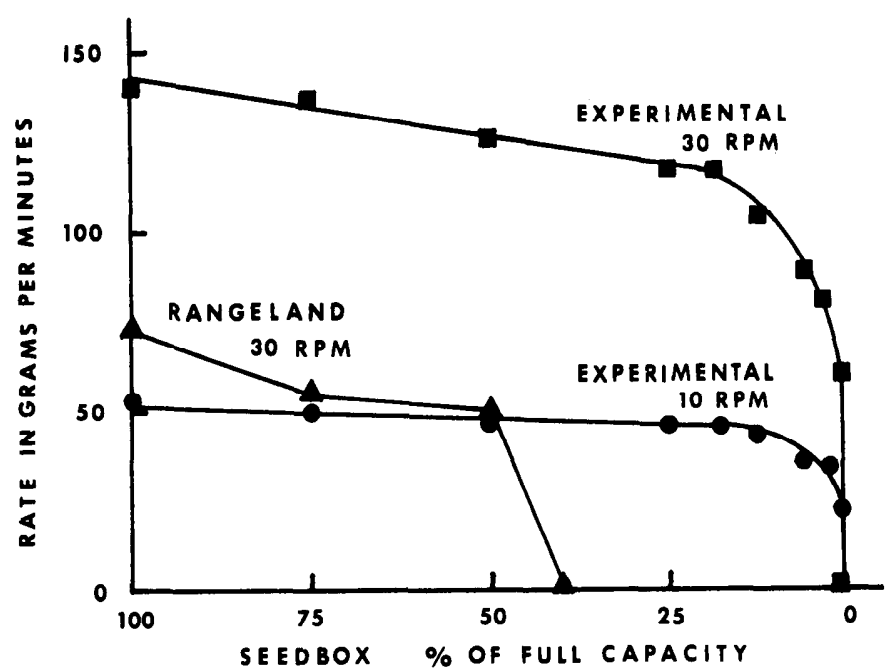

Fig. 1. Comparison of uniform seeding rate of the experimental metering device, a semicircular seedbox and auger agitator, to the nonuniform rates of the standard rangeland seed metering device, courtesy of American Society of Agricultural Engineers.

metered $97 \%$ of the seed from the seedbox during static test conditions.

A Planet Junior mechanism was selected to meter small, slick seed because of its wide use on Nesbit and other drills. The unit gave erratic seed metering because trash and irregular size seed plugged the small metering orifice. A John Deere, double-run, internal cup-feed seeding mechanism (part number AN 161321) was selected for the experimental seeder and has functioned well using a variety of trashy seed.

Laboratory and field tests of both seed metering concepts were evaluated under a broad range of conditions. Results have been very promising (Wiedemann 1975, Wiedemann and Brock 1975, Wiedemann et al. 1976, and Wiedemann et al. 1980).

\section{Seeder Prototype}

The semicircular seedbox was constructed from $30-\mathrm{cm}$ (12-in) steel pipe and the open-center auger was fabricated from 10-gauge steel. Pickerwheels were placed on $30-\mathrm{cm}(12-i n)$ centers in the 1.8-m (6-ft) long seedbox. Individual seedboxes were constructed from 14-gauge steel for the six, cup-feed seeding devices. All seedboxes were mounted on a heavy-duty frame constructed with 76.2 $\times 76.2 \times 6.4-\mathrm{mm}(3 \times 3 \times 1 / 4$-in) steel tubing with $41 \mathrm{~cm}(16$ in) of ground clearence (Fig. 2). A special hitch was built that would oscillate and articulate to allow necessary movement between the seeder and tractor as they traversed rough land.

A flexing, runner opener was designed to place the seed in the seedbed without undue breakage from stumps, and other debris up to 12 inches in diameter (Fig. 3). The runner opener, $50.8 \times$

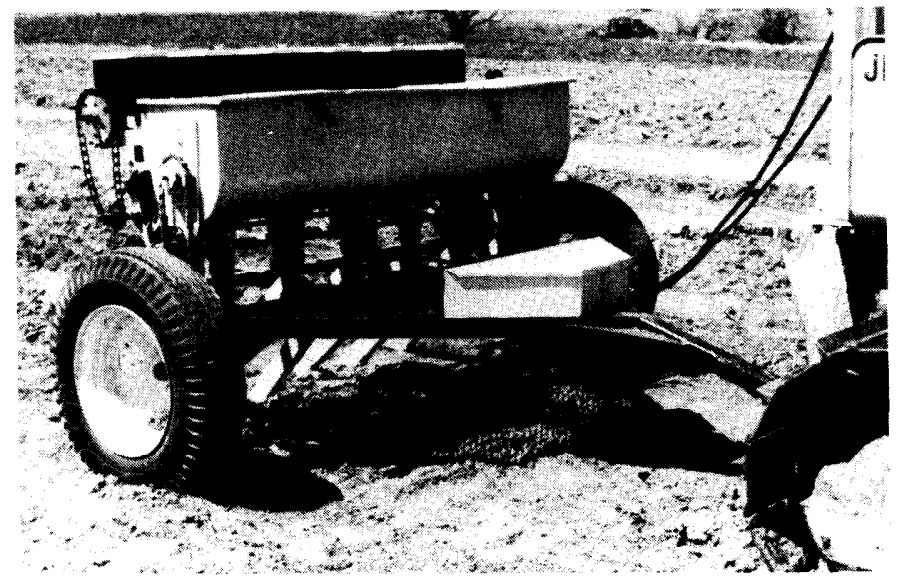

Fig. 2. Semicircular seedbox with auger agitator (for fluffy seed) and individual seedboxes with cup-feed metering mechanism (for small, slick seed) mounted on heavy-duty frame with 8-ply tire.

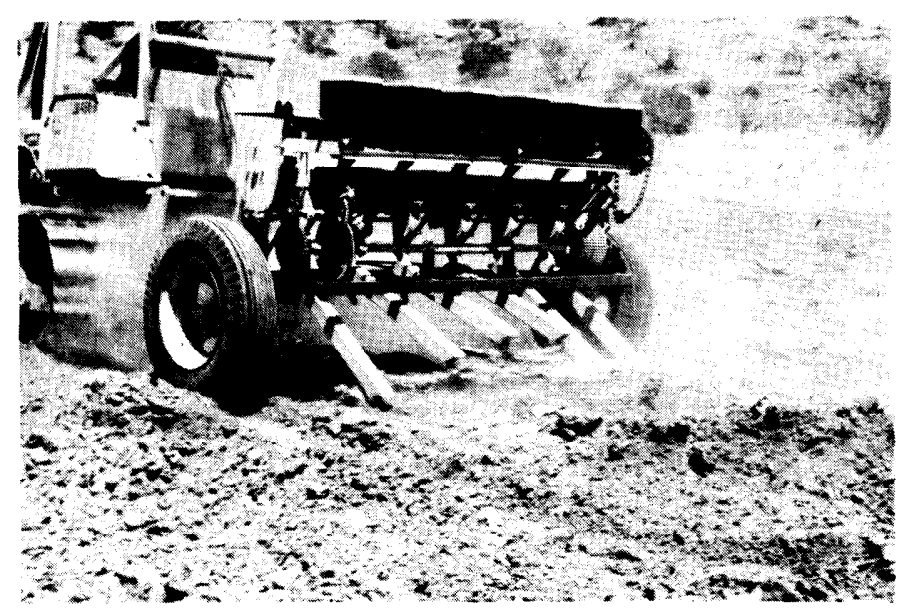

Fig. 3. Experimental rangeland seeder equipped with flexing, running openers to place seed in seed furrow without undue mechanical breakage from logs up to $30 \mathrm{~cm}$ (12 in) in diameter.

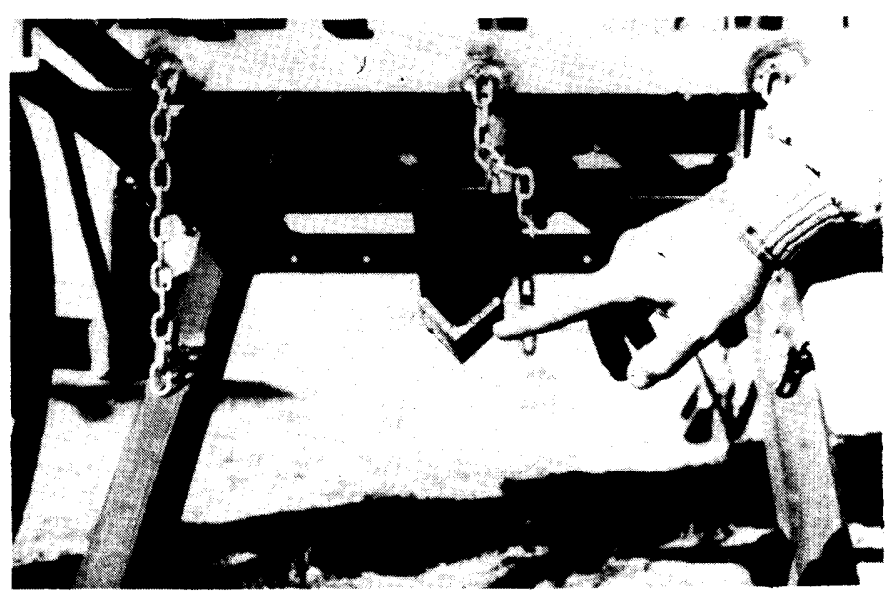

Fig. 4. V-shape wedge welded to runner-opener forms desired seed furrow and the tubular steel opener also serves as seed tube.

76.2-mm ( $2 \times 3$-in) rectangular steel tubing, also served as the seed tube. A V-shaped wedge welded to the bottom of the seed tube (Fig. 4), formed the desired furrow to trap the dispensed seed (Wiedemann et al. 1971). Openers for each pickerwheel were individually pinned to the frame to facilitate broadcast and row seedings. Lifting of the openers and termination of seed dispensing was controlled by a single hydraulic cylinder. 
Field performance of the experimental rangeland seeder has been excellent and 5-years of testing is extensively covered by Wiedemann et al. (1979). The seeder has operated successfully on seedbeds prepared by chaining, rollerchopping or discing following rootplowing when sparse amounts of logs and stumps up to 30 $\mathrm{cm}$ (12 in) in diameter or sparse to moderate amounts of lesser debris were present.

\section{Literature Cited}

Brock, J.H., E.D. Robison, C.E. Fisher, and C.H. Meadors. 1970. Reestablishment of grasses following mechanical removal of brush. Tex. Agr. Exp. Sta. PR 2810 In: Consol. PR 2801-2828:43.

Wiedemann, H.T., L.E. Wilkes, and O.R. Kunze. 1971. Design for optimum performance of a furrow opener to plant cottonseed in humid arcas. Transaction of the ASAE 14(5):919-923.
Wiedemann, H.T. 1975. Improving seed metering and seed placement devices for rangeland drills. Rangeland Resources Research 1971-1974, Tex. Agr. Exp. Sta. Consol. PR-3341:36-37.

Wiedemann, H.T., and J.H. Brock 1975. Reseeding as affected by seedbed preparation, seeding methods and seeding rates following root plowing. Rangeland Resources Research 1971-1974, Tex. Agr. Exp. Sta. Consol. PR 3341:38-40.

Wiedemann, H.T., J.H. Brock, and C.E. Fisher. 1976. Seed metering and placement devices for rangeland seeder. Amer. Soc. Agr. Eng. paper no. 76-1571, Chicago, Ill.

Wiedemann, H.T., J.H. Brock, B.T. Cross, and V.E. Jones. 1978. Development of seeding equipment and techniques for reseeding rough, loglittered root-plowed rangeland. Abstracts of papers, 31st Annual Meeting Society for Range Management. p. 17.

Wiedemann, H.T., J.H. Brock, C.E. Fisher, and B.T. Cross. 1980. Seed metering and placement devices for rangeland seeder. Transaction of the ASAE 22:972-977.

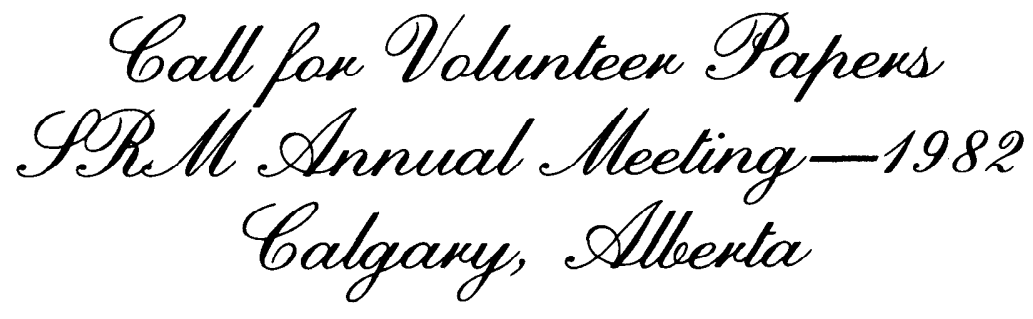

August 15 is the deadline to submit a preliminary title for each volunteer paper you propose to present at Calgary. We will accommodate all worthy volunteer papers within the policy guidelines established in our initial announcement.

The following calendar details the procedures for volunteer papers: 1) Preliminary Titles: Deadline, August 15. Indicate general program category. Send titles to Alex Johnston, c/o Lands Division, AENR, Sun Center 530 8th St. South, Lethbridge, Alta. Canada T1J 2J8. You may submit more than one title per category, but you will be called on later to prioritize these to guide us if we have to be selective during program synthesis (see program policy).

2) Abstracts and Finished Titles: These will be submitted on blue-line forms which we will send you after we get your preliminary title(s).

Alex Johnston, Program Chairman 